УДК 321.244

DOI https://doi.org/10.32849/2663-5313/2019.8.23

\title{
Андрій Деркач,
}

канд. юрид. наук, народний депутат України,

докторант Інституту законодавства Верховної Ради Украйни

\section{МІЖНАРОДНО-ПРАВОВІ СТАНДАРТИ ЗАХИСТУ ПРАВ ЛЮДИНИ ТА ЇХ ВІДОБРАЖЕННЯ В КОНСТИТУЩІЇ УКРАЇНИ}

У статті аналізується низка глобальних міжнародних актів, що містять стандарти забезпе чення та захисту прав і основоположних свобод людини і громадянина, що знайшли своє відображення в розділі II Конституиії України. Проаналізовано роль судової практики Європейського суду з прав людини та Міжнародного суду ООН у становленні та процесі впровадження стандартів захисту прав і свобод людини. Наголошено, що Всесвітня конференція з прав людини у преамбулі до декларащії враховує, що заохочення $i$ захист прав людини є питанням першорядного значення для міжнародно20 співтовариства, і ио Конферениія надає унікальну можливість для проведення всебічного аналізу міжнародної системи прав людини і механізму захисту прав людини з метою зміцнення $і$ заохочення більш повного дотримання иих прав справедливим і збалансованим чином, визнає і стверджує, що всі права людини є наслідком гідності і цінності, притаманних людській особистості, і що людська особистість є иенттральним суб'єктом прав людини і основних свобод i, відповідно, повинна бути основним бенефічіаром иих прав і свобод і активно брати участь в їх реалізачї̈, підтверджуючи свою прихильність цілям і принципам, що містяться в Статуті Організацї̈ Об'єднаних Націй і у Загальній декларації прав людини. Наголошено, що прецедентна практика Європейського суду з прав людини нині фактично є елементом національної правової системи, оскільки сама Свропейська конвенція про захист прав людини та основоположних свобод дає Суду право тлумачити положення Конституиіі України, а начіональні судові органи починають дедалі більще посилатися на його судові рішення під час вирішення питань у межах наиіональної судової юрисдикиї. Зроблено висновок, що законодавство України з прав людини і насамперед Конституція нашої держави відповідають міжнародно-правовим стандартам. Так, незважаючи на прогрес у законодавчій сфері, в Україні існує потреба у вдосконаленні правозастосовної практики та впровадженні в дію названих міжнародних стандартів, зокрема через використання судової практики Європейського суду з прав людини та Міжнародного суду ООН. До того ж вступ України до Ради Європи зобов'язує дотримуватися міжнародних норм $і$ принципів у галузі захисту прав людини.

Ключові слова: захист прав людини, конституційна процедура захисту прав людини, міжнародні стандарти, глобальні міжнародні стандарти, Конституційний Суд України.

Постановка проблеми. Сфера захисту прав і свобод людини більше не є полем діяльності винятково однієї країни. Наразі ця сфера належить до напряму діяльності більшості міжнародних організацій. Сьогодні нараховується більше 300 декларацій, конвенцій, хартій, що мають за мету задекларувати та закріпити на глобальному світовому рівні основоположні права та свободи людини і їх захисту та відновлення у випадку їх порушення. Такі міжнародно-правові акти в галузі прав людини зазвичай розглядаються як міжнародні стандарти, оскільки засновані на звичаєвих нормах, що сформувалися внаслідок визнання державами юридичної сили правил поведінки, які були проголошені Генеральною Асамблеєю ООН у вигляді декларацій чи рекомендацій. Саме ця низка міжнародно-правових актів стала базисом для Конституції України та закріплює гарантії забезпечення і дотримання прав і свобод людини і громадянина в Україні.

Метою статті є дослідження особливостей глобальних міжнародно-правових стандартів захисту прав і свобод людини в рамках конституційної юстиції.

Виклад основного матеріалу. Міжнародні стандарти в галузі прав людини - це загальновизнані міжнародно-правові норми, які закріплюють на загальнолюдському рівні статус особистості і встановлюють перелік основоположних прав і свобод, обов'язок держав дотримуватися цих прав і свобод, а також межі можливого або припустимого їх обмеження [1, с. 2]. Так, до основних актів, що містять глобальні стандарти прав і сво- 
бод особи та стосуються правового статусу людини і громадянина та 3 якими узгоджуються приписи Конституції України і відповідних нормативно-правових актів, можна віднести: Загальну декларацію прав людини (1948), Міжнародний пакт про громадянські та політичні права (1966), Міжнародний пакт про економічні, соціальні та культурні права (1966), Європейську конвенцію про захист прав людини та основоположних свобод 3 протоколами (1950), Європейський соціальний стандарт (1961), Заключний акт Наради 3 питань безпеки та співробітництва в Європі (1975), Підсумковий документ Віденської зустрічі представників держав - учасниць Наради з питань безпеки та співробітництва в Свропі (1989), Документ Копенгагенської наради - конференції з людського виміру НБСЕ (1990) тощо.

Слід також зупинити увагу на Статуті ООН від 26 червня 1945 р., який дозволяе стверджувати, що питанням прав людини присвячені декілька положень цього документу. Насамперед це теза преамбули Статуту щодо нового затвердження «віри в основні права людини, в гідність та цінність людської особистості» та приписи ст. 55 Статуту, за якими, з метою утворення умов сталості та добробуту, необхідних для мирних та дружніх відносин між націями, заснованих на повазі принципу рівноправ'я та самовизначення народів, ООН має сприяти загальній повазі та дотриманню «прав людини та основних свобод для усіх, без розрізнення раси, статі, мови та релігії». Тотожне визначення прав та свобод людини формулювання містить й п. «b» ч. 1 ст. 13 Статуту, за яким Генеральна Асамблея ООН (далі - ГА ООН) повинна організовувати дослідження та робити рекомендації з метою сприяння міжнародній співпраці, зокрема, в сфері сприяння здійсненню цих прав. За ч. 2 ст. 62 Статуту Економічна та Соціальна Рада ООН також уповноважена робити рекомендації з метою «заохочення поваги та дотримання прав людини та основних свобод для усіх» [2].

Основний Закон нашої держави зорієнтований на міжнародно-правові стандарти. 3 огляду на це в них значна увага приділяється регулюванню співвідношення і взаємодії норм внутрішнього і міжнародного права. Україна, дотримуючись загальновизнаних принципів і норм міжнародного права, на конституційному рівні встановила чіткий порядок введення в дію цих норм. Так, норми міжнародного права, у тому числі і ті, що стосуються прав і свобод людини, стають частиною національного законодавства за умови надання згоди на обов'язковість міжнародних договорів Верховною Радою України.
Наприклад, розділ II Конституції присвячений правам і свободам людини і громадянина, а в цілій низці статей знайшли своє відображення положення Загальної декларації прав людини [3]. Виходячи з положень Декларації «усі люди народжуються вільними і рівними у своїй гідності і правах» (ст. 1), а згідно зі ст. 2 кожній людині належать права і свободи, проголошені цією Декларацією, незалежно від раси, кольору шкіри, статі, мови, релігії, політичних або інших переконань, національного або станового походження, майнового чи іншого стану тощо. Вкажемо на приписи її окремих статей, що безперечно вплинули на подальший розвиток національних моделей конституціоналізму та на глобалізацію цього правового феномену, зокрема та насамперед у сфері захисту прав особи [4].

Так, можна із неї виокремити такі загальні міжнародні стандарти щодо прав людини, як рівність прав всіх людей та їх рівний захист законом, не дискримінація, право людини на ефективне поновлення у правах компетентними національними судами в разі порушення іï̈ основних прав, гарантії кримінально-процесуальних прав людини (ст. ст. 7, 8, 10 і т.д. ЗДПЛ) [4].

Серед документів універсальної дії варто навести й Віденську декларацію та Програму дій, схвалені на Всесвітній конференції 3 прав людини 25 червня 1993 р. Так, Всесвітня конференція 3 прав людини у преамбулі до декларації враховує, що заохочення і захист прав людини є питанням першорядного значення для міжнародного співтовариства, і що Конференція надає унікальну можливість для проведення всебічного аналізу міжнародної системи прав людини і механізму захисту прав людини з метою зміцнення і заохочення більш повного дотримання цих прав справедливим і збалансованим чином, визнає і стверджує, що всі права людини $€$ наслідком гідності і цінності, притаманних людській особистості, і що людська особистість є центральним суб'єктом прав людини і основних свобод і, відповідно, повинна бути основним бенефіціаром цих прав і свобод і активно брати участь у їх реалізації, підтверджуючи свою прихильність цілям і принципам, що містяться в Статуті Організації Об’єднаних Націй і у Загальній декларації прав людини. Крім того, у ст. 83 Віденської декларації міститься припис урядам - зміцнити національні структури, інститути й органи суспільства, які відіграють певну роль у справі заохочення та захисту прав людини та водночас імплементувати в законодавстві міжнародні стандарти прав людини [5].

Також слід визнати значущість резолюції ГА ООН 48/137 від 20 грудня 1993 р. «Права 
людини в адмініструванні юстиції» за якою вичерпну значущість для захисту прав людини мають незалежність судочинства, суддів та юристів, право на справедливий вирок, habeas corpus та дотримання прав людини за надзвичайних обставин, аспекти попереднього ув'язнення, покарання неповнолітніх та безкарності винних у порушенні прав людини [6]. На тій самій сесії резолюцією ГА ООН 48/134 було затверджено Принципи стосовно статусу національних інститутів сприяння та захисту прав людини (Паризькі принципи) [6].

У резолюції 48/134 підкреслювалося, що ефективна імплементація міжнародних стандартів прав людини є можливою винятково за наявності заходів та інституцій на національному рівні. Такі інституції мають не тільки підтримувати та захищати права людини, але й розвивати публічну свідомість щодо таких прав та свобод. При цьому саме ООН відводилася роль сприяння розвитку таких інституцій в якості місця обміну інформацією та досвідом; важливими для таких інституцій визначалися їх незалежність та плюралізм у формуванні складу, констатувалася потреба їх утворення чи посилення спроможності [6].

Крім того, Конституція України передбачила можливість звернення громадян України до спеціальних міжнародних установ із питань вирішення спорів, що стало посиленням права на захист порушених прав і свобод національними засобами захисту [3]. До таких установ належать Міжнародний Суд ООН, Європейський суд з прав людини тощо. Згідно із ст. 55 Конституції кожен має право після використання всіх національних засобів правового захисту звертатися за захистом своїх прав і свобод до відповідних міжнародних установ чи до відповідних органів міжнародних організацій, членом або учасницею яких є Україна.

Найважливішу роль у запровадженні відповідних стандартів відіграє Європейський суд 3 прав людини, який діє відповідно до Європейської конвенції про захист прав людини та основоположних свобод 1950 р., що набула чинності в Україні у вересні 1997 р. Саме з цього часу започатковано якісно новий підхід до імплементації правозахисних стандартів, яким надається конкретна правова форма. Прецедентна практика Європейського суду з прав людини нині фактично є елементом національної правової системи, оскільки сама Європейська конвенція про захист прав людини та основоположних свобод дає Суду право тлумачити положення Конституції України, а національні судові органи починають дедалі більше посилатися на його судові рішення під час вирішення питань у межах національної судової юрисдикції [1, с. 2]. Слід також наголосити, що зазначеному стану речей сприяє практика численних звернень громадян України до нього.

\section{Висновки}

Підсумовуючи, вкажемо, що сьогодні законодавство України 3 прав людини i насамперед Конституція нашої держави відповідають міжнародно-правовим стандартам. Так, незважаючи на прогрес у законодавчій сфері, в Україні існує потреба у вдосконаленні правозастосовної практики та впровадженні в дію названих міжнародних стандартів, зокрема, через використання судової практики Європейського суду з прав людини та Міжнародного суду ООН. До того ж вступ України до Ради Європи зобов'язує дотримуватися міжнародних норм і принципів у галузі захисту прав людини.

\section{Список використаних джерел:}

1. Шевчук С. Судовий захист прав людини: Практика Європейського суду з прав людини у контексті західної правової традиції. Київ : Реферат, 2006. С. 2

2. Статут Організації Об'єднаних Націй і Статут Міжнародного Суду від 26 червня 1945 p. URL: https://zakon.rada.gov.ua/laws/show/995_010.

3. Конституція України: затверджена Законом України від 28 червня 1996 р. № 254к / 96ВР (із змінами, внесеними Законом України від 1 лютого 2011 р. № 2952-VI (2952-17). Відомості Верховної Ради України. 1996. № 30. Ст. 141 ; 2011. № 10. Ст. 68.

4. Загальна декларація прав людини від 10.12.1948. URL: https://zakon.rada.gov.ua/laws/ show/995_015.

5. Віденську декларацію та Програму дій, схвалені на Всесвітній конференції з прав людини 25 червня 1993 p. URL: https://zakon.rada.gov.ua/ laws/show/995 504.

6. National Institutions for the Promotion and Protection of Human Rights : Resolution 48/134 adopted by the UN General Assembly on 20 December 1993 [on the report of the Third Committee (A/48/632/Add.2)]. URL: https://undocs.org/en/A/RES/48/134.

The article analyzes a number of global international acts containing standards for the protection and defense of the rights and fundamental freedoms of man and citizen, which are reflected in Section II of the Constitution of Ukraine. The role of judicial practice of the European Court of Human Rights and the International Court of Justice in the development and implementation of standards for the protection of human rights and freedoms is analyzed. It is emphasized that the World Conference on Human Rights in the preamble 
to the Declaration takes into account that the promotion and protection of human rights is a matter of paramount importance to the international community and that the Conference provides a unique opportunity for a comprehensive analysis of the international human rights system and the mechanism for the protection of human rights in order to strengthen and thus encouraging the full respect of these rights in a fair and balanced manner, recognizes and asserts that all human rights are a consequence of the dignity and worth of the human dignity and that the human person is a central subject of human rights and fundamental freedoms and, accordingly, should be the main beneficiary of these rights and freedoms and actively participate in their implementation, Reaffirming their commitment to the purposes and principles contained in the Charter of the United Nations and in the Universal Declaration of Human Rights. It has been pointed out that the case law of the European Court of Human Rights is actually an integral part of the national legal system, since the European Convention on Human Rights protects the right to interpret the provisions of the Constitution of Ukraine and the national courts increasingly rely on its judgments resolving issues within national jurisdictional jurisdiction. It is concluded that the legislation of Ukraine on human rights and, above all, the Constitution of our country comply with international legal standards. Thus, in spite of legislative progress, there is a need for improved enforcement practice in Ukraine and the introduction of the named international standards, in particular through the use of the jurisprudence of the European Court of Human Rights and the International Court of Justice. In addition, Ukraine's accession to the Council of Europe obliges to adhere to international norms and principles in the field of human rights protection.

Key words: protection of human rights, constitutional procedure for the protection of human rights, international standards, global international standards, the Constitutional Court of Ukraine. 